\title{
Sea cucumbers reduce chromophoric dissolved organic matter in aquaculture tanks
}

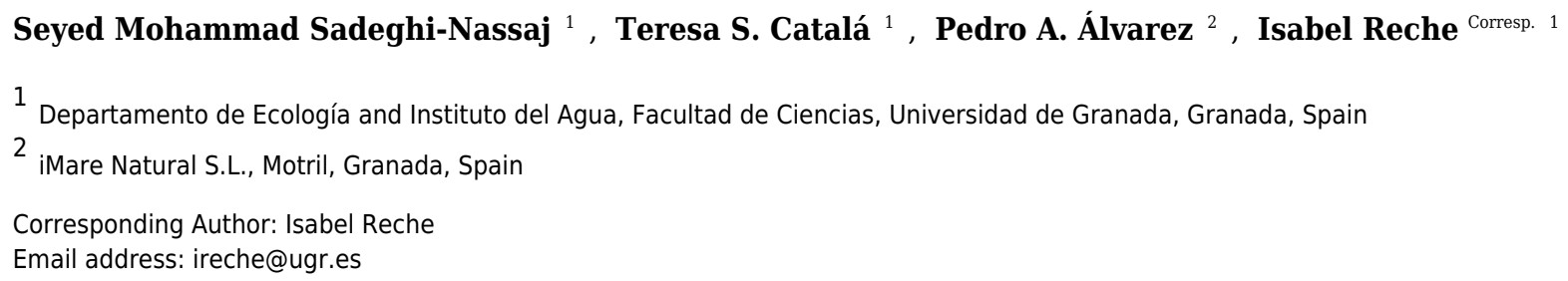

Background. Mono-specific aquaculture effluents contain high concentrations of nutrients and organic matter, which affect negatively the water quality of the recipient ecosystems. A fundamental feature of water quality is its transparency. The fraction of dissolved organic matter that absorbs light is named chromophoric dissolved organic matter (CDOM). A sustainable alternative to mono-specific aquaculture is the multitrophic aquaculture that includes species trophically complementary named "extractive" species that uptake the waste byproducts. Sea cucumbers are recognized as efficient extractive species due to the consumption of particulate organic matter (POM). However, the effects of sea cucumbers on CDOM are still unknown. Methods. During more than one year, we monitored CDOM in two big-volume tanks with different trophic structure. One of the tanks (-holothurian) only contained around 810 individuals of Anemonia sulcata, whereas the other tank (+ holothurian) also included 90 individuals of Holothuria tubulosa and $\mathrm{H}$. forskali. We routinely analyzed CDOM absorption spectra and determined quantitative (absorption coefficients at $325 \mathrm{~nm}$ ) and qualitative (spectral slopes) optical parameters in the inlet waters, within the tanks, and in their corresponding effluents. To confirm the time-series results, we also performed three experiments. Each experiment consisted of two treatments: + holothurians $(+\mathrm{H})$ and -holothurians $(-\mathrm{H})$. We set up three $+\mathrm{H}$ tanks with 80 individuals of $A$. sulcata and 10 individuals of $H$. tubulosa in each tank and four $-\mathrm{H}$ tanks that contained only 80 individuals of $A$. sulcata. Results. In the time-series, absorption coefficients at $325 \mathrm{~nm}\left(\mathrm{a}_{325}\right)$ and spectral slopes from 275 to $295 \mathrm{~nm}\left(\mathrm{~S}_{275-295}\right)$ were significantly lower in the effluent of the +holothurian tank (average: $0.33 \mathrm{~m}^{-1}$ and 16 $\mu \mathrm{m}^{-1}$, respectively) than in the effluent of the -holothurian tank (average: $0.69 \mathrm{~m}^{-1}$ and 34 $\mu \mathrm{m}^{-1}$, respectively), the former being similar to those found in the inlet waters (average: $0.32 \mathrm{~m}^{-1}$ and $22 \mu \mathrm{m}^{-1}$, respectively). This reduction in the absorption of the dissolved organic matter appears to be mediated by the POM consumption by holothurians. The experiments confirmed the results observed in the time-series. The $a_{325}$ and $S_{275-295}$ values 
were significantly lower in the treatment with holothurians than in the treatment without holothurians indicating a reduction in the concentration of chromophoric organic compounds, particularly of low molecular weight. Discussion. Consequently, sea cucumbers appear to improve water transparency in aquaculture tanks. The underlying mechanism of this improvement might be related to the POM consumption by holothurians; which reduces the concentration of CDOM derived from POM disaggregation or to the direct assimilation of dissolved compounds of low molecular weight as chromophoric amino acids. 
1 Sea cucumbers reduce chromophoric dissolved organic matter in aquaculture tanks

2 Seyed Mohammad Sadeghi-Nassaj ${ }^{1}$, Teresa S. Catalá ${ }^{1}$, Pedro A. Álvarez ${ }^{2}$, and Isabel Reche ${ }^{1}$

$3{ }^{1}$ Departamento de Ecología and Instituto del Agua, Facultad de Ciencias, Universidad de

4 Granada, 18071 Granada, Spain

52 iMare Natural S.L., Av. de la Habana 10, 18600 Motril, Granada, Spain

6 Corresponding author:

7 Isabel Reche

$8 \quad$ Email address: ireche@ugr.es 
10 Abstract:

11 Background. Mono-specific aquaculture effluents contain high concentrations of nutrients and

12 organic matter, which affect negatively the water quality of the recipient ecosystems. A

13 fundamental feature of water quality is its transparency. The fraction of dissolved organic matter

14 that absorbs light is named chromophoric dissolved organic matter (CDOM). A sustainable

15 alternative to mono-specific aquaculture is the multitrophic aquaculture that includes species

16 trophically complementary named "extractive" species that uptake the waste byproducts. Sea

17 cucumbers are recognized as efficient extractive species due to the consumption of particulate

18 organic matter (POM). However, the effects of sea cucumbers on CDOM are still unknown.

19 Methods. During more than one year, we monitored CDOM in two big-volume tanks with

20 different trophic structure. One of the tanks (-holothurian) only contained around 810 individuals

21 of Anemonia sulcata, whereas the other tank (+ holothurian) also included 90 individuals of

22 Holothuria tubulosa and H. forskali. We routinely analyzed CDOM absorption spectra and

23 determined quantitative (absorption coefficients at $325 \mathrm{~nm}$ ) and qualitative (spectral slopes)

24 optical parameters in the inlet waters, within the tanks, and in their corresponding effluents. To

25 confirm the time-series results, we also performed three experiments. Each experiment consisted

26 of two treatments: + holothurians $(+\mathrm{H})$ and -holothurians $(-\mathrm{H})$. We set up three $+\mathrm{H}$ tanks with 80

27 individuals of $A$. sulcata and 10 individuals of $H$. tubulosa in each tank and four $-\mathrm{H}$ tanks that

28 contained only 80 individuals of $A$. sulcata. Results. In the time-series, absorption coefficients at

$29325 \mathrm{~nm}(\mathrm{a} 325)$ and spectral slopes from 275 to $295 \mathrm{~nm}$ (S275-295) were significantly lower in

30 the effluent of the +holothurian tank (average: 0.33 and $16 \mu \mathrm{m}-1$, respectively) than in the

31 effluent of the -holothurian tank (average: $0.69 \mathrm{~m}-1$ and $34 \mu \mathrm{m}-1$, respectively), the former being

32 similar to those found in the inlet waters (average: $0.32 \mathrm{~m}-1$ and $22 \mu \mathrm{m}-1$, respectively). This

33 reduction in the absorption of the dissolved organic matter appears to be mediated by the POM

34 consumption by holothurians. The experiments confirmed the results observed in the time-series. 
35 The $\mathrm{a}_{325}$ and $\mathrm{S}_{275-295}$ values were significantly lower in the treatment with holothurians than in the

36 treatment without holothurians indicating a reduction in the concentration of chromophoric

37 organic compounds, particularly of low molecular weight. Discussion. Consequently, sea

38 cucumbers appear to improve water transparency in aquaculture tanks. The underlying

39 mechanism of this improvement might be related to the POM consumption by holothurians;

40 which reduces the concentration of CDOM derived from POM disaggregation or to the direct

41 assimilation of dissolved compounds of low molecular weight as chromophoric amino acids. 


\section{Introduction}

The exponential growth of human population has boosted the global demand of fish and

44 seafood (FAO, 2009). Nevertheless, the extractive fisheries are more and more reduced and the

45 aquaculture is gaining importance accounting for more than $40 \%$ of human consumption of fish

46 and seafood (Bostock et al., 2010). Mono-specific aquaculture produces wastewater that usually

47 contains high concentrations of organic matter as well as inorganic nutrients, antibiotics and

48 uneaten food pellets (Read \& Fernandes, 2003; Klinger \& Naylor, 2012). At ecosystem level, the

49 effluents of mineral nutrients associated with the aquaculture activity can produce problems of

50 eutrophication (Ajin et al., 2016; Ruiz-Zarzuela et al., 2009). On the other hand, the loads of

51 dissolved and particulate organic matter with the effluents can reduce water transparency due to

52 an increase in light backscattering and absorption (Ibarra et al. 2012; Del Bel Belluz et al. 2016).

53 Therefore, a sustainable aquaculture with effluents of low environmental impact is a global

54 challenge for both scientists and food producers. The polyculture and the integrated multitrophic

55 aquaculture (IMTA) is an alternative practice to alleviate the handicaps of the traditional, mono-

56 specific aquaculture (Diana et al., 2013). Unlike mono-specific aquaculture, polyculture and

57 IMTA uses trophically complementary "extractive" species that consume the excretion products,

58 fecal and food wastes of the primary species reducing these loads in the effluents (Chopin et al.

59 2012). Hence, it is desirable that the future expansion of aquaculture promotes this practice to

60 reduce the inputs of organic matter in the environment, at the same time that aquaculture farmers

61 can obtain an economical value from the co-cultured species.

62 The chromophoric dissolved organic matter (CDOM) is the fraction of the dissolved

63 organic matter (DOM) that absorbs light in the ultraviolet (UV) and, to a lesser extent, in the

64 visible range of the spectrum. Therefore, CDOM is largely responsible for UV and blue light

65 attenuation in marine ecosystems (Bricaud et al., 1981; Nelson \& Siegel, 2013). Since CDOM 
66 absorption overlaps one of the chlorophyll a absorption peaks, CDOM can diminish the potential

67 for primary productivity. This fact also affects the algorithms used in remote sensing to determine

68 ocean color and infer primary productivity (Carder et al. 1989; Siegel et al., 2005; Ortega-

69 Retuerta et al., 2010). Remote sensing has been suggested as an excellent tool to monitor at large

70 scale the impact of offshore aquaculture (Populus et al., 1995; Rajitha et al., 2007; Saitoh et al.,

71 2011). However, the relation between aquaculture waste and CDOM has been scarcely explored

72 (Ibarra et al. 2012; Nimptsch et al. 2015; Del Bel Belluz et al. 2016).

73 Sea cucumbers are highly demanded food for human consumption in some countries

74 (Purcell et al. 2013), but they are also important extractive species with a high capacity to

75 consume waste particulate organic matter in sediment deposits (Nelson et al. 2012a,b; Yokoyama

76 2013, 2015). Despite the effects of sea cucumbers on different components of the particulate

77 organic matter has been studied, particularly in open waters under fish cages or mollusk rafts

78 (Slater \& Carton 2009; Slater et al. 2009; Nelson et al., 2012a Zamora \& Jeff 2011; Yokoyama

2013, 2015; Zhang et al., 2014), their influence on the optical properties of the dissolved organic matter still remains unexplored (Zamora et al., 2016). The influence of sea cucumbers on the optical properties of the organic matter can be relevant in land-based installations submitted to

82 long-term water recirculation.

In this study, we evaluate the effects of sea cucumbers (Holothuria tubulosa and $H$.

84 forskali) on optical properties of the dissolved organic matter in aquaculture tanks with Anemonia sulcata as primary species. A. sulcata is a very palatable species, highly demanded for catering in Spain with also a great pharmacological interest. During one year, we monitored the changes in DOM optical properties in a big-volume (50,000 liters) tank with holothurians and in another similar tank without them, exploring the main factors that determine CDOM changes. 
90 we performed three short-term experiments manipulating the presence of holothurians in small

91 tanks (300 liters). We observed, both in the time-series of the big tanks and in the short-term

92 experiments, that the presence of holothurians reduced significantly the absorption due to

93 dissolved organic matter increasing, consequently, the water transparency in comparison with the

94 tanks without holothurians. Therefore, holothurians appear to have a high environmental value to

95 improve the water quality in aquaculture installations.

\section{Material and Methods}

97 Time-series in the big-volume tanks

98 We monitored during more than one year two aquaculture tanks located at the iMareNatural S.L.

99 facilities (http://www.imarenatural.com) in Motril, Spain $\left(36^{\circ} 44^{\prime} 38^{\prime \prime} \mathrm{N}, 3^{\circ} 35^{\prime} 59^{\prime \prime} \mathrm{W}\right)$. Each tank

100 of 50,000 liters of capacity was connected directly with the coastal water by one inlet pipe (inlet

101 water) and the water from each tank was released by one outlet pipe located in the bottom of the

102 tank (effluent). The seawater was pumped into the tanks at a continuous flow of 1,200 $1 \mathrm{~h}^{-1}$.

103 Therefore, water residence time in the tanks was ca. 42 hours and the total annual effluents

104 accounted for $10,512 \mathrm{~m}^{3}$. In one of the tanks, $811 \pm 125$ individuals of the primary species, the

105 sea anemone Anemonia sulcata, and $93 \pm 3$ adults of sea cucumbers Holothuria tubulosa $(\approx 80$

$106 \%$ ) and $H$. forskali $(\approx 20 \%)$ were included (hereafter designated as + holothurian tank). In the

107 other tank only $690 \pm 87$ individuals of the primary specie were included (hereafter designated as

108 - holothurian tank). Sea anemones were placed on floating plastic boxes in the surface of the

109 tanks and holothurians were free in the bottom and walls of the tanks. Sea anemones were fed

110 with about 900-1800 g of fresh chopped fish, mainly Scomber scombrus (Chintiroglou and

111 Koukouras 1992) twice per week.

112 Water samples for different chemical and biological analysis were taken biweekly from

113 July $17^{\text {th }} 2013$ to August $20^{\text {th }} 2014$. Each sampling day, we took water samples from the inlet 
114 pipe, the center of the two tanks using a telescopic stick with a plastic beaker located in its

115 extreme and from their corresponding effluents. To avoid that light can affect absorption

116 measurements; we immediately took the CDOM samples in pre-combusted ( $4 \mathrm{~h}$ at $\left.500{ }^{\circ} \mathrm{C}\right)$, acid-

117 cleaned, amber glass bottles. They were kept in ice during transportation to the laboratory (about

118 one hour from the tanks). Water samples were filtered through pre-combusted Whatman $\mathrm{GF} / \mathrm{F}$

119 glass fiber filters of $0.7 \mu \mathrm{m}$ nominal pore size and the $<0.7 \mu \mathrm{m}$ fraction was used for the optical

120 characterization of chromophoric dissolved organic matter.

\section{Chromophoric Dissolved Organic Matter (CDOM)}

122 Absorption spectra of dissolved organic matter provide information on CDOM

123 concentration and other qualitative properties. Absorption coefficients at specific wavelengths

124 (e.g. $325 \mathrm{~nm}$ and $443 \mathrm{~nm}$ ) are used as proxies of CDOM concentration, and the spectral slopes

125 and spectral ratios, which are largely independent of the concentration, are surrogates of CDOM

126 origin, molecular weight and chemical structure (Weishaar et al., 2003; Twardowski et al., 2004;

127 Helms et al., 2008; Nelson and Siegel, 2013; Martínez-Pérez et al. 2017).

128 CDOM absorbance spectra were recorded at wavelengths from $200 \mathrm{~nm}$ to $750 \mathrm{~nm}$ at 1-nm

129 interval using an UV/VIS Perkin Elmer spectrometer with a $10 \mathrm{~cm}$-quartz cuvette. The

130 spectrophotometer was connected to a computer with Lambda 25 software. The detection limit of

131 the spectrophotometer (0.001 Absorbance) corresponds to a CDOM absorption coefficient

132 detection limit of $0.02 \mathrm{~m}^{-1}$. Spectrum corrections due to residual scattering by fine size particle

133 fractions, micro-air bubbles, or colloidal material present in the sample were performed by

134 subtracting the average of the absorption between 600 and $700 \mathrm{~nm}$ (Green and Blough, 1994).

135 CDOM absorption coefficients, $a_{\lambda}$, were calculated using the next equation: 


$$
a_{\lambda}=2.303 \frac{\text { Absorbance }(\lambda)-\text { Absorbance }(600-700)}{l}
$$

137 Where $a_{\lambda}$ is the absorption coefficients in $\mathrm{m}^{-1}$ at each $\lambda$ wavelength, Absorbance $(\lambda)$ is the

138 absorbance at wavelength $\lambda$, Absorbance (600-700) is the average absorbance from 600 to 700

$139 \mathrm{~nm}, 2.303$ is the factor that converts decadic to natural logarithms, $l$ is the cuvette path length in $140 \mathrm{~m}^{-1}$.

142 Slopes were calculated from the linear regression of log-transformed absorption coefficients in 143 the wavelength bands $275-295 \mathrm{~nm}\left(\mathrm{~S}_{275-295}\right)$ and $350-400 \mathrm{~nm}\left(\mathrm{~S}_{350-400}\right)$ (Helms et al. 2008). The 144 spectral slopes for both wavelength ranges were calculated as in equation 2.

$$
a_{\lambda}=a_{\lambda r e f} e^{-S\left(\lambda-\lambda_{\text {ref }}\right)}
$$

146 Where $\lambda$ is the selected wavelength in $\mathrm{nm}, a_{\lambda}$ is the absorption coefficient at $\lambda$ wavelength in $\mathrm{m}^{-1}$, $147 a_{\lambda r e f}$ is the absorption coefficient at a reference wavelength $\lambda_{\text {ref, }}$ and $S$ is the spectral slope. The 148 spectral slope ratio $\left(S_{R}\right)$ was calculated as the ratio of the spectral slope from $275 \mathrm{~nm}$ to $295 \mathrm{~nm}$ $149\left(\mathrm{~S}_{275-295}\right)$ to the spectral slope from $350 \mathrm{~nm}$ to $400 \mathrm{~nm}$ (Helms et al., 2008). CDOM absorption usually decreases exponentially as wavelengths increase. Therefore,

151 the shorter the wavelength, the more sensitive to changes is (Fig. 1). Despite a low sensitivity

152 (Fig. 1), the visible wavelength at $443 \mathrm{~nm}$ is used in remote sensing studies due to its

153 correspondence with the satellite sensor (Siegel et al., 2005; Ortega-Retuerta et al., 2010).

154 Therefore, the spectral slope from $275 \mathrm{~nm}$ to $295 \mathrm{~nm}$ is the most sensitive optical parameter of 155 CDOM changes (Helms et al., 2008), but this parameter is not quantitative. CDOM quantity was 156 measured as absorption coefficient at $325 \mathrm{~nm}\left(\mathrm{a}_{325}\right)$, since this wavelength is the most common in 
157 the literature (Nelson \& Siegel 2013; Catalá et al. 2015) and has a higher sensitivity than $443 \mathrm{~nm}$ 158 (Fig.1).

159 Ancillary data

160 Basic parameters as temperature $\left({ }^{\circ} \mathrm{C}\right), \mathrm{pH}$, salinity (psu), total dissolved solids (TDS), and

161 conductivity (mScm-1) were measured in the tanks using a multi-parameter HANNA probe

162 (HI9828 model). Total organic carbon (TOC) concentration was measured as non-purgeable

163 organic carbon after a high-temperature catalytic oxidation using a Shimadzu TOC-V CSN.

164 Samples, by triplicate, were acidified with hydrochloric acid and purged for 20 min to eliminate

165 the remaining dissolved inorganic carbon. Three to five injections were analyzed for each sample.

166 Standardization of the instrument was done with potassium hydrogen phthalate. Particulate

167 organic matter (POM) was obtained filtering between 1.5 and 2.01 of water through pre-weighed

168 and pre-combusted $\left(500^{\circ} \mathrm{C}\right.$ for $\left.4 \mathrm{~h}\right)$ Whatman $\mathrm{GF} / \mathrm{F}$ glass fiber filters. The filters containing all

169 the solids were dried at $60^{\circ} \mathrm{C}$ for $>24 \mathrm{~h}$ and reweighed to determine the total mass (mineral +

170 organic matter). Then, the organic fraction was burned by combusting the filters at $500^{\circ} \mathrm{C}$ for $6 \mathrm{~h}$;

171 finally, the filters were reweighed again to determine the mineral residue. POM was obtained

172 after the subtraction of the mineral residue to the total mass. The concentration of chlorophyll- $a$

173 was determined spectrophotometrically after pigment extraction with methanol (APHA 1992).

174 Bacteria abundance was determined in triplicate using flow cytometry (Gasol and del Giorgio

175 2000) with a FACScalibur Becton Dickinson cytometer equipped with a laser emitting at $488 \mathrm{~nm}$.

176 Data were processed using Cell quest software.

178 To test the statistical significance of the results obtained in the time-series, we performed three

179 short-term (3 days) experiments. Each experiment was carried out in seven tanks of 300 liters that 
180 contained a floating plastic box with 80 individuals of $A$. sulcata per tank and consisted of two

181 treatments: + holothurians $(+\mathrm{H})$ and -holothurians $(-\mathrm{H})$. At the initial time, in three of the tanks

182 we included 10 individuals of $H$. tubulosa in each tank. These three tanks are the replicates of the

183 +holothurians treatment. The other four tanks only contained the 80 individuals of $A$. sulcata and

184 represent the replicates of the -holothurians treatment. The experiment 1 was carried out from $6^{\text {th }}$

185 to $9^{\text {th }}$ October 2017 , the experiment 2 from $27^{\text {th }}$ to $30^{\text {th }}$ October 2017 , and the experiment 3 from

$1863^{\text {rd }}$ to $6^{\text {th }}$ November 2017. During the duration of each experiment the anemones were not fed to

187 control the net effect of holothurian activity. At the initial and final time we took samples for the

188 optical characterization of dissolved organic matter. To analyze the samples we followed the

189 same procedures used in the time-series.

190 Statistical analysis

191 To compare the time-series of the CDOM optical parameters in the inlet water with the effluents

192 from the tank with holothurians and the tank without holothurians we performed paired t-test (for

193 normally distributed variables) and Wilcoxon matched pairs test (for not-normally distributed

194 variables) using the Statistica software (V8). These statistical analyses ameliorate the problem of

195 temporal pseudoreplication in this type of studies (Millar and Anderson 2004). Correlations

196 between CDOM optical parameters and potential controlling factors were performed using

197 Statistica software (V8). In the short-term experiments to test the statistical significance of the

198 presence of holothurians on the CDOM optical parameters we performed analysis of variance

199 (ANOVA) comparing the tanks with holothurians $(+\mathrm{H})$ with the tanks without holothurians $(-\mathrm{H})$

200 using Statistica software (V8).

201 Results and discussion 
202 During the study period, the $\mathrm{pH}$ in the inlet waters ranged from 7.71 to 8.31 , the temperature

203 from $13.58{ }^{\circ} \mathrm{C}$ to $25.58^{\circ} \mathrm{C}$, the salinity from 35.8 to $41.6 \mathrm{psu}$, the conductivity between 52.28 and

$20461.96 \mathrm{mS} \mathrm{cm}{ }^{-1}$ and total dissolved solids from 18.26 to $30.84 \mathrm{ppt}$. These basic parameters were

205 similar in the tanks and in their corresponding effluents (Tables S1-S5).

206 Time-series of the optical parameters in the big-volume tanks

207 In the inlet waters, the $\mathrm{a}_{325}$ values ranged from 0.06 to $0.83 \mathrm{~m}^{-1}$ (Table $\mathrm{S} 1$ ) and in the effluents of

208 +holothurian and -holothurian tanks from 0.06 to $0.79 \mathrm{~m}^{-1}$ and from 0.37 to $1.27 \mathrm{~m}^{-1}$,

209 respectively (Tables S2 and S3). The absorption coefficients of the inlet waters (i.e. coastal

210 waters of Western Mediterranean Sea) were similar to those ones found in other coastal waters

211 (Catalá et al. 2013; Nima et al., 2016) or in the open Mediterranean Sea (Bracchini et al., 2010;

212 Organelli et al. 2014). Systematically, throughout the time-series, the effluent of the -holothurian

213 tank showed higher $a_{325}$ values (grey triangles in Fig. 2a) than the effluent of the + holothurian

$214 \operatorname{tank}$ (red squares in Fig. 2a). These last values were similar to the $\mathrm{a}_{325}$ values in the inlet waters

215 (white circles).

216 Spectral slopes and spectral slope ratios are qualitative parameters, which are independent

217 of the CDOM concentration. The higher the spectral slope, the smaller the DOM molecular

218 weight is (Helms et al., 2008). The slope in the band from $275 \mathrm{~nm}$ to $295 \mathrm{~nm}\left(\mathrm{~S}_{275-295}\right)$ is an

219 optical parameter particularly sensitive to environmental changes as solar radiation or salinity

220 (Helms et al. 2008; 2013; Catalá et al. 2013). In the inlet water, the values of $\mathrm{S}_{275-295}$ ranged from

22110 to $38 \mu \mathrm{m}^{-1}$ (Table S1) and in the effluents of tholothurian and -holothurian tanks from 6 to 28

$222 \mu \mathrm{m}^{-1}$ and from 13 to $40 \mu \mathrm{m}^{-1}$, respectively (Tables S2 and S3). In the inlet water, the values were

223 similar to those reported for coastal and estuary waters, usually characterized with lower slopes

$224\left(\sim 15-25 \mu \mathrm{m}^{-1}\right)$ than the values for the open ocean $\left(\sim 25-50 \mu \mathrm{m}^{-1}\right)($ Helms et al., 2008; 2013 Catalá 
225 et al., 2015). Like the $\mathrm{a}_{325}$ values, the $\mathrm{S}_{275-295}$ values in the effluent waters of the -holothurian tank

226 (grey triangles in Fig. 2b) showed consistently higher values than the inlet water (white circles in

227 Fig. 2b) and in the effluents of the +holothurian tank (red squares in Fig. 2b). In the inlet waters,

228 the spectral slope ratios $\left(\mathrm{S}_{\mathrm{R}}\right)$ ranged from 0.6 to 2.6 (Table $\mathrm{S} 1$ ) and in the effluents of

229 +holothurian and -holothurian tanks from 0.5 to 3.1 and from 0.4 to 3.9, respectively (Tables S2

230 and S3). The $S_{R}$ values in -holothurian effluents (grey triangles in Fig. 2c) showed consistently

231 higher values than the inlet water (white circles in Fig. 2c) and +holothurian effluent (red squares 232 in Fig. 2c).

233 To assess if the presence of holothurians can modify significantly CDOM we performed

234 paired t-test or Wilcoxon matched pair tests pooling all the time-series data (Table 1). In the Fig.

2353 we show all the time-series data pooled in median values, $25-75 \%$ percentiles and non-outliers

236 values. The $\mathrm{a}_{325}$ values in the -holothurian tank and effluent (Fig. 3a, grey boxes) were

237 significantly higher that the values in the +holothurian tank and effluent and the inlet water

238 (Table 1). A similar effect was found for the spectral slope $\left(\mathrm{S}_{275-29}\right)$ (Fig. 3b, grey boxes), and the

239 spectral ratios $\left(\mathrm{S}_{\mathrm{R}}\right)$ (Fig. 3c, grey boxes). Indeed, we observed higher CDOM concentration with

240 higher spectral slopes (surrogate of smaller molecular size, Helms et al. 2008) in the tank without

241 holothurians than in the tank with holothurians. Therefore, holothurians appear to reduce

242 significantly CDOM concentration, particularly of compounds with comparatively lower

243 molecular weight making the spectral slopes smaller. On the other hand, the differences between

244 the inlet water and the +holothurian tank and effluent water, although significant, were less

245 relevant (Fig. 3, Table 1).

246 These results suggest that effluent of the monoculture of $A$. sulcata increases CDOM in

247 comparison with the inlet water, which could affect the recipient coastal waters. These higher

248 CDOM values in the -holothurian tank in comparison with the values in +holothurian tank could 
249 be related to: (1) a higher abundance of bacteria and their metabolic by-products that produce

$250 \mathrm{CDOM}$ or (2) a higher concentration of particulate organic matter (derived from uneaten food,

251 detritus and microbial cells) which disaggregation in dissolved compounds also produce CDOM.

252 In both cases, an increment in CDOM concentration is expected in absence of holothurians.

253 Several studies have shown that bacteria and phytoplankton can produce CDOM as metabolic by-

254 products (Nelson et al., 1998, 2004; Ortega-Retuerta et al. 2009; Romera-Castillo et al. 2010;

255 Catalá et al. 2015; 2016). However, we did not find significant relationships between the $\mathrm{a}_{325}$

256 values and the concentration of chlorophyll- $a$ (+holothurian $r^{2}=0.009, p=0.513$; -holothurian $r^{2}=$

$2570.002 \mathrm{p}=0.804)$ or the abundance of bacteria $\left(+\right.$ holothurian $\mathrm{r}^{2}=0.014, \mathrm{p}=0.403$; -holothurian $\mathrm{r}^{2}=$

$2580.068 \mathrm{p}=0.095)($ Fig. $4 \mathrm{a})$. Therefore, phytoplankton and bacterial carbon processing appear to

259 have a minor importance in these tanks. In contrast, we found significant and positive

260 relationships between the concentration of particulate organic matter (POM) and the $\mathrm{a}_{325}$ values in

261 the +holothurian tank and effluent water (red squares; $\mathrm{r}^{2}=0.41, \mathrm{p}=0.002$; regression line $\mathrm{a}_{325}=$

$2620.20+0.079 \mathrm{POM}$ ) and the $\mathrm{a}_{325}$ values in the -holothurian tank and effluent water (grey triangles;

$263 \mathrm{r}^{2}=0.20, \mathrm{p}=0.006$; regression line $\mathrm{a}_{325}=0.42+0.102$ POM) (Fig. 4b). Therefore, POM

264 concentration in the tanks appears to be the main driver of CDOM changes. POM disaggregation

265 into dissolved components is a common process in coastal waters (He et al. 2016), particularly

266 under sunny conditions (Shank et al., 2011; Pisani, et al. 2011). Holothurians consume several

267 components of POM as phytoplankton cells, bacteria, uneaten food, animal feces, and transparent

268 exopolymer particles (Hudson et al., 2005; Slater et al., 2009; Navarro et al., 2013; Yokoyama,

269 2013; Wotton, 2011). Since holothurians reduce POM concentration by consumption in these

270 tanks (Sadeghi-Nassaj et al. in prep.), we think that POM disaggregation into DOM in the tank

271 with holothurians was significantly lower than in the tank without holothurians where a relevant

272 fraction of POM might have been converted into CDOM. In addition, recently Brothers et al.

273 (2015) have demonstrated a direct uptake of free amino acids in several tissues as the respiratory 
274 trees, epidermis, and oral tentacles of a sea cucumber species (Parastichopus californicus) during

275 the visceral regeneration. It is well known that amino acids such as the tyrosine and tryptophan

276 are able to absorb light in the ultraviolet band (e.g. Catalá et al. 2013). Therefore, a direct and

277 selective assimilation of free amino acids by holothurians could also explain a reduction in the

$278 \mathrm{a}_{325}$ values and in the spectral slopes.

Short-term experiments

280 To corroborate the results obtained in the time-series, we performed three short-term ( 3 days)

281 experiments in smaller tanks manipulating the presence of holothurians. At the initial time, we

282 did not observe significant differences in the optical parameters between both treatments $(+\mathrm{H}$ and

$283-\mathrm{H}$ ) indicating the experiments started with identical conditions with the exception of the

284 presence of holothurians (Table 2). However, at the final time after three days, the presence of

285 holothurians ( $+\mathrm{H}$ treatment) significantly reduced the values of the CDOM absorption

286 coefficients at $325 \mathrm{~nm}\left(\mathrm{a}_{325}\right)$ in 2 out of 3 experiments (Fig. 5a red bars, Table 2) and in 1 out of 3

287 experiments at $443 \mathrm{~nm}\left(\mathrm{a}_{443}\right)$ (Fig. $5 \mathrm{~b}$ red bars, Table 2). In the three experiments, at the final

288 time, the presence of holothurians $(+\mathrm{H}$ treatment $)$ reduced significantly the spectral slopes $\left(\mathrm{S}_{275-}\right.$

289 295) (Fig. 5c red bars, Table 2). This variability in the statistical significance for the different

290 optical parameters is related to the inherent higher sensitivity of CDOM as wavelengths are

291 shorter (see Fig.1).

\section{Conclusions}

293 Overall, we found that the presence of holothurians in aquaculture tanks reduces significantly the

294 concentration of CDOM, particularly of compounds with relatively lower molecular size. A

295 plausible mechanism for this reduction is the consumption of particulate organic matter by

296 holothurians reducing its disaggregation into chromophoric dissolved compounds. 
297 Complementary, holothurians could also consume directly dissolved compounds as chromophoric

298 amino acids. This fact can affect positively water transparency. Indeed, CDOM optical

299 parameters in the tank with holothurians in the time-series were quite similar to the inlet water

300 both quantitatively (similar absorption coefficients at $325 \mathrm{~nm}$ ) and qualitatively (similar spectral

301 slopes and ratios) avoiding the increment of color in the waste effluents observed in the tank

302 without holothurians. In offshore aquaculture installations, the presence of holothurians could

303 also affect positively water transparency by reducing light absorption and scattering (Ibarra et al.

304 2012; Del Bel Belluz et al. 2016) as particulate organic matter settle down and they are placed

305 below fish cages. Monitoring CDOM optical properties in aquaculture installations is an easy and

306 inexpensive procedure very sensitive to the changes caused by the extractive species helping in

307 the control of aquaculture waste. Therefore, the use of CDOM probes, for long-term monitoring,

308 or remote sensing for large spatial scales, is a promising research area for the development of a

309 sustainable aquaculture.

310 All data for CDOM optical parameters and ancillary variables are in supplementary material

311 (Table S1, S2, S3, S4, and S5).

\section{ACKNOWLEDGEMENTS}

313 The authors thank Eulogio Corral Arredondo for help during the samplings, Ana Ortiz with the

314 logistic in the aquaculture tanks, and Gustavo Ortiz Ferrón for his help with flow cytometry for 315 bacterial abundance. 


\section{References}

317 Ajin AM, Silvester R, Alexander D, Nashad M, Abdulla MH. 2016. Characterization of blooming 318 algae and bloom-associated changes in the water quality parameters of traditional pokkali cum 319 prawn fields along the South West coast of India. Environmental Monitoring and Assessment 320 188:145. DOI:10.1007/s10661-016-5133-6.

APHA. 1992. Standard Methods for the Examination of Water and Wastewater. 18th edition. Washington,D.C.: American Public Health Association.

324 Handisyde N, Gatward I, Corner R. 2010. Aquaculture: global status and trends. Philosophical

325 Transactions of the Royal Society B 365:2897-2912. DOI: 10.1098/rstb.2010.0170.

326

327

328

329

330

331

332

333

334

335

336

337

338

339

340

341

342

343

344

345

346

347

348

349

350

351

352
Bracchini L, Tognazzi A, Dattilo AM, Decembrini F, Rossi C, Loiselle SA. 2010. Sensitivity analysis of CDOM spectral slope in artificial and natural samples: an application in the central eastern Mediterranean Basin. Aquatic Sciences 72:485-498. DOI:10.1007/s00027-010-0150-y.

Bricaud A, Morel A, Prieur L. 1981. Absorption by dissolved organic matter of the sea (yellow substance) in the UV and visible domains. Limnology and Oceanography 26:43-53. DOI: 10.4319/1o.1981.26.1.0043.

Brothers CJ, Lee RW, Nestler JR. 2015. The uptake of dissolved organic material by the sea cucumber Parastichopus californicus (Stimpson) and its potential role in visceral regeneration. Journal of Experimental Marine Biology and Ecology 469: 69-75. DOI:

10.1016/j.jembe.2015.04.016.

Carder KL, Steward RG, Harvey GR, Ortner PB. 1989. Marine humic and fulvic acids: their effects on remote sensing of ocean chlorophyll. Limnology and Oceanography 34:68-8. DOI: 10.4319/1o.1989.34.1.0068.

Catalá TS, Mladenov N, Echevarría F, Reche I. 2013. Positive trends between salinity and chromophoric and fluorescent dissolved organic matter in a seasonally inverse estuary. Estuarine, Coastal and Shelf Science 133:206-216. DOI: org/10.1016/j.ecss.2013.08.030.

Catalá TS, Reche I, Álvarez M, Khatiwala S, Guallart EF, Benítez-Barrios VM, Fuentes-Lema A, Romera-Castillo C, Nieto-Cid M, Pelejero C, Fraile-Nuez E, Ortega-Retuerta E, Marrasé C, Álvarez-Salgado XA. 2015. Water mass age and aging driving chromophoric dissolved organic matter in the dark global ocean. Global Biogeochemical Cycles 29:917-934.

DOI:10.1002/2014GB005048.

Catalá TS, Reche I, Ramón CL, López-Sanz A, Álvarez M, Calvo E, Álvarez-Salgado XA. 2016. Chromophoric signatures of microbial by-products in the dark ocean. Geophysical Research Letters 43:7639-7648. DOI:10.1002/2016GL069878.

Chintiroglou C, Koukouras A. 1992. The feeding habits of three Mediterranean Sea anemone species, Anemonia viridis (Forskal), Actinia equina (Linnaeus) and Cereus pedunculatus (Pennant). Helgoländer Meeresuntersuchungen 46:53-68. DOI: 10.1007/BF02366212. 
353 Chopin T, Cooper JA, Reid G, Cross S, Moore C. 2012. Open-water integrated multi-trophic 354 aquaculture: environmental biomitigation and economic diversification of fed aquaculture by 355 extractive aquaculture. Reviews in Aquaculture 4:209-220. DOI: 10.1111/j.1753-

356 5131.2012.01074.x.

357 Del Bel Belluz J, Costa M, Reid G, Cross S. 2016. Bio-optical variability at a Vancouver Island 358 aquaculture site. Limnology and Oceanography 61:1686-1704. DOI:10.1002/lno.10332.

359 Diana JS, Egna HS, Chopin T, Peterson MS, Cao L, Pomeroy R, Verdegem M, Slack WT, 360 Bondad-Reantaso MG, Cabello F. 2013. Responsible Aquaculture in 2050: Valuing Local 361 Condition and Human Innovation will be Key to Success. Bioscience 63:255-262.

362 DOI:10.1525/bio.2013.63.4.5.

363 FAO(Food and Agriculture Organization of the United Nations). 2009. The state of world 364 fisheries and aquaculture 2008.Rome:Food and Agriculture Organization of the United 365 Nations.Available at http://www.fao.org/docrep/011/i0250e/i0250e00.htm.

366 Gasol JM, del Giorgio PA. 2000. Using flow cytometry for counting natural planktonic bacteria 367 and understanding the structure of planktonic bacterial communities. Scientia Marina 64:197368 224. DOI:10.3989/scimar.2000.64n2197.

369 Green SA, Blough NV. 1994. Optical absorption and fluorescence properties of chromophoric 370 dissolved organic matter in natural waters. Limnology and Oceanography 39:1903-1916.

371 He W, Chen M, Schlautman MA, Hur J. 2016. Dynamic exchanges between DOM and POM 372 pools in coastal and inland aquatic ecosystems: A review. Science of the Total Environment 551373 552:415-428. DOI: 10.1016/j.scitotenv.2016.02.031.

374 Helms JR, Stubbins A, Ritchie JD, Minor EC, Kieber DJ, Mopper K. 2008. Absorption spectral slopes and slope ratios as indicators of molecular weight, source, and photobleaching of 376 chromophoric dissolved organic matter. Limnology and Oceanography 53:955-969.

377 DOI:10.4319/10.2008.53.3.0955.

378 Helms, JR, Stubbins A, Perdue EM, Green NW, Chen H, Mopper K. 2013. Photochemical 379 bleaching of oceanic dissolved organic matter and its effect on absorption spectral slope and 380 fluorescence. Marine Chemistry 155:81-91. DOI:10.1016/j.marchem.2013.05.015.

381 Hudson IR, Wigham BD, Solan M, Rosenberg R. 2005. Feeding behavior of deep- sea dwelling 382 holothurians: Inferences from a laboratory investigation of shallow fjords species. Journal of 383 Marine Systems 57:201-218. DOI:10.1016/j.jmarsys.2005.02.004.

384 Ibarra DA, Cembella A, Grant J. 2012. Attenuation of sunlight measured from moored 385 radiometers to assess depletion of suspended particles caused by bivalve aquaculture. Limnology 386 and Oceanography: Methods 10:1051-1069. DOI:10.4319/lom.2012.10.1051.

387 Klinger D, Naylor R. 2012. Searching for solutions in aquaculture: charting a sustainable course. 388 Annual Review of Environment and Resources 37:247-276. DOI:10.1146/annurev-environ389 021111-161531. 
390 Martínez-Pérez AM, Nieto-Cid M, Osterholz H, Catalá TS, Reche I, Dittmar T, Álvarez-Salgado

391 XA. 2017. Linking optical and molecular signatures of dissolved organic matter in the

392 Mediterranean Sea. Scientific Reports 7:3436 DOI:10.1038/s41598-017-03735-4.

393 Millar RB, Anderson MJ. 2004. Remedies for pseudoreplication. Fisheries Research 70:397-407. 394 DOI:10.1016/j.fishres.2004.08.016.

395 Navarro PG, García-Sanz S, Barrio JM, Tuya F. 2013. Feeding and movement patterns of the sea 396 cucumber Holothuria sanctori. Marine Biology 160:2957-2966. DOI:10.1007/s00227-013-22863975.

398 Nelson EJ, MacDonald BA, Robinson SMC. 2012a. The absorption efficiency of the suspension399 feeding sea cucumber, Cucumaria frondosa, and its potential as an extractive integrated multi400 trophic aquaculture (IMTA) species. Aquaculture 370-371:19-25.

401 DOI:10.1016/j.aquaculture.2012.09.029.

402 Nelson EJ, MacDonald BA, Robinson SMC. 2012b. A Review of the Northern Sea Cucumber 403 Cucumaria frondosa (Gunnerus, 1767) as a Potential Aquaculture Species. Reviews in Fisheries 404 Science 20:212-219. DOI:10.1080/10641262.2012.719043.

405 Nelson, NB, Siegel DA, Michaels AF. 1998. Seasonal dynamics of colored dissolved material in 406 the Sargasso Sea. Deep Sea Research Part I 45:931-957. DOI:10.1016/S0967-0637(97)00106-4.

407 Nelson NB, Carlson CA, Steinberg DK. 2004. Production of chromophoric dissolved organic 408 matter by Sargasso Sea microbes. Marine Chemistry 89:273-287.

409 DOI:10.1016/j.marchem.2004.02.017.

410 Nelson NB, Siegel DA. 2013. The global distribution and dynamics of chromophoric dissolved 411 organic matter. Annual Review of Marine Science 5:447-476. DOI: 10.1146/annurev-marine412 120710-100751.

413 Nima C, Frette E, Hamre B, Erga SR, Chen YC, Zhao L, Sørensen K, Norli M, Stamnes K, 414 Stamnes JJ. 2016. Absorption properties of high-latitude Norwegian coastal water: The impact of 415 CDOM and particulate matter. Estuarine, Coastal and Shelf Science 178:158-167.

416 DOI:10.1016/j.ecss.2016.05.012.

417 Nimptsch J, Woelfl S, Osorio S, Valenzuela J, Ebersbach P, Tuempling WV, Palma R, Encina F, 418 Figueroa D, Kamjunke N, Graeber D. 2015. Tracing dissolved organic matter (DOM) from land419 based aquaculture systems in North Patagonian streams. Science of the Total Environment. 420 537:129-138. DOI:10.1016/j.scitotenv.2015.07.160.

421 Organelli E, Bricaud A, Antoine D, Matsuoka A. 2014. Seasonal dynamics of light absorption by 422 chromophoric dissolved organic matter (CDOM) in the NW Mediterranean Sea (BOUSSOLE 423 site). Deep-Sea Research Part I. 91:72-85. DOI:10.1016/j.dsr.2014.05.003.

424 Ortega-Retuerta E, Frazer TK, Duarte CM, Ruiz-Halpern S, Tovar-Sánchez A, Arrieta JM, Reche 425 I. 2009. Biogeneration of chromophoric dissolved organic matter by bacteria and krill in the 426 Southern Ocean. Limnology and Oceanography 54:1941-1950. DOI:10.4319/1o.2009.54.6.1941. 
427 Ortega-Retuerta E, Siegel DA, Nelson NB, Duarte CM, Reche I. 2010. Observations of

428 chromophoric dissolved and detrital organic matter distribution using remote sensing in the

429 Southern Ocean: validation, dynamics and regulation. Journal of Marine Systems 82:295-303.

430 DOI:10.1016/j.jmarsys.2010.06.004.

431 Pisani O, Yamashita Y, Jaffé R. 2011. Photo-dissolution of flocculent, detrital material in aquatic

432 environments: Contributions to the dissolved organic matter pool. Water Research 45: 3836-

433 3844. DOI:10.1016/j.watres.2011.04.035.

434 Populus J, Hastuti W, Martin J-L M, Guelorget O, Sumartono B, Wibowo A. 1995. Remote

435 sensing as a tool for diagnosis of water quality in Indonesian seas. Ocean \& Coastal Management

436 27:197-215. DOI:10.1016/0964-5691(95)00033-X.

437 Purcell SW, Mercier A, Conand C, Hamel J-F, Toral-Granda MV, Lovatelli A, Uthicke S. 2013.

438 Sea cucumber fisheries: global analysis of stocks, management measures and drivers of

439 overfishing. Fish and Fisheries 14:34-59. DOI:10.1111/j.1467-2979.2011.00443.x.

440 Rajitha K, Mukherjee CK, Vinu Chandran R. 2007. Applications of remote sensing and GIS for

441 sustainable management of shrimp culture in India. Aquacultural Engineering 36:1-17.

442 DOI:10.1016/j.aquaeng.2006.05.003.

443 Read P, Fernandes T. 2003. Management of environmental impacts of marine aquaculture in

444 Europe. Aquaculture 226:139-163. DOI:10.1016/S0044-8486(03)00474-5.

445 Romera-Castillo C, Sarmento H, Alvarez-Salgado XA, Gasol JM, Marrase C. 2010. Production

446 of chromophoric dissolved organic matter by marine phytoplankton. Limnology and

447 Oceanography 55:446-454. DOI:10.4319/10.2010.55.1.0446.

448 Ruiz-Zarzuela I, Halaihel N, Balcázar J, Ortega C, Vendrell D, Pérez T, Alonso J, de Blas I. 2009.

449 Effect of fish farming on the water quality of rivers in northeast Spain. Water Science and

450 Technology 60:663-671. DOI: 10.2166/wst.2009.435.

451 Saitoh S-I, Mugo R, Radiarta IN, Asaga S, Takahashi F, Hirawake T, Ishikawa Y, Awaji T, In T, 452 Shima S. 2011. Some operational uses of satellite remote sensing and marine GIS for sustainable 453 fisheries and aquaculture. ICES Journal of Marine Science 68:687-695.

454 DOI:10.1093/icesjms/fsq190.

455 Shank GC, Evans A, Yamashita Y, Jaffé R. 2011. Solar radiation-enhanced dissolution of 456 particulate organic matter from coastal marine sediments. Limnology and Oceanography 56:577457 588. DOI:10.4319/1o.2011.56.2.0577.

458 Siegel DA, Maritorena S, Nelson NB, Behrenfeld MJ, McClain CR. 2005. Colored dissolved 459 organic matter and its influence on the satellite-based characterization of the ocean biosphere.

460 Geophysical Research Letter 32. DOI: 10.1029/2005GL024310.

461 Slater MJ, Carton AG. 2009. Effect of sea cucumber (Australostichopus mollis) grazing on 462 coastal sediments impacted by mussel farm deposition. Marine Pollution Bulletin 58:1123-1129. 463 DOI:10.1016/j.marpolbul.2009.04.008. 
464 Slater MJ, Jeffs AG, Carton AG. 2009. The use of the waste from green-lipped mussels as a food 465 source for juvenile sea cucumber, Australostichopus mollis. Aquaculture 292:219-224.

466 DOI:10.1016/j.aquaculture.2009.04.027.

467 Twardowski MS, Boss E, Sullivan JM, Donaghay PL. 2004. Modeling the spectral shape of 468 absorption by chromophoric dissolved organic matter. Marine Chemistry 89:69-88.

469 DOI:10.1016/j.marchem.2004.02.008.

470 Weishaar JL, Aiken GR, Bergamaschi BA, Fram MS, Fujii R, Mopper K. 2003. Evaluation of 471 specific ultraviolet absorbance as an indicator of the chemical composition and reactivity of 472 dissolved organic carbon. Environmental Science Technology 37:4702-4708.

473 DOI:10.1021/es030360x.

474 Wotton RS. 2011. EPS (Extracellular Polymeric Substances), silk, and chitin: vitally important 475 exudates in aquatic ecosystems. Journal of the North American Benthological Society 30:762476 769. DOI:10.1899/10-120.1.

477 Yokoyama H. 2013. Growth and food source of the sea cucumber Apostichopus japonicus 478 cultured below fish cages. Potential for integrated multi-trophic aquaculture. Aquaculture 372479 375: 28-38. DOI:10.1016/j.aquaculture.2012.10.022.

480 Yokoyama H. 2015. Suspended culture of the sea cucumber Apostichopus japonicus below a 481 Pacific oyster raft potential for integrated multi-trophic aquaculture. Aquaculture Research 482 46:825-832. DOI:10.1111/are.12234.

483 Zamora LN, Jeffs AG. 2011. Feeding, selection, digestion and absorption of the organic matter 484 from mussel waste by juveniles of the deposit-feeding sea cucumber, Australostichopus mollis. 485 Aquaculture 317:223-228. DOI:10.1016/j.aquaculture.2011.04.011.

486 Zamora LN, Yuan X, Carton AG, Slater MJ. 2016. Role of deposit-feeding sea cucumbers in 487 integrated multitrophic aquaculture: progress, problems, potential and future challenges. Reviews 488 in Aquaculture. DOI:10.1111/raq.12147.

489 Zhang L, Gao Y, Zhang T, Yang H, Xu Q, Sun L, Yu Z. 2014. A new system for bottom co-culture 490 of the scallop, Patinopecten yessoensis, with the sea cucumber, Apostichopus japonicus, and the 491 sea urchin, Anthocidaris crassispina, in shallow water in China. Aquaculture International 492 22:1403-1415. 


\section{Figure captions}

494 Figure 1 Exponential decay of absorption coefficients as wavelengths increase from the ultraviolet to the visible band. Example of a decay curve of the chromophoric dissolved organic matter in a sample taken on January $30^{\text {th }}$ of 2014 from the big-volume tank that contains holothurians. The wavelengths selected for the calculation of the optical parameters used in this study are marked on the decay curve.

Figure 2 Time-series of the optical parameters of chromophoric dissolved organic matter in the big-volume tanks. Values of (a) absorption coefficients at $325 \mathrm{~nm}$ (a325), (b) spectral slopes from 275 to $295 \mathrm{~nm}\left(\mathrm{~S}_{275-295}\right)$, and (c) spectral slope ratios $\left(\mathrm{S}_{\mathrm{R}}\right)$ in the inlet water effluent water of the -holothurian tank (grey triangles).

Figure 3 Median values (line), the $25-75 \%$ percentiles (box), and the non-outliers ranges (whisker) of the optical parameters of chromophoric dissolved organic matter pooling time-series data. Values of (a) absorption coefficients at $325 \mathrm{~nm}$ (a325), (b) spectral slopes

510 Figure 4 Scatterplots of absorption coefficients at $325 \mathrm{~nm}$ (a325) vs. bacterial abundance (a) and particulate organic matter (b) of the time-series data. Red squares are the values for the +holothurian (effluent and tank) waters and grey triangles are the values for the - 
513 holothurian (effluent and tank) waters. Correlation lines are shown only when are

$514 \quad$ statistically significant $(\mathrm{p}<0.05)$.

515 Figure 5 Changes in optical parameters of chromophoric dissolved organic matter in the three

516 experiments. Mean (bars) and the standard deviations (whiskers) of the replicates of (a)

517 absorption coefficients at $325 \mathrm{~nm}$ (a325), (b) absorption coefficients at $443 \mathrm{~nm}$ (a443),

518 and (c) spectral slopes from 275 to $295 \mathrm{~nm}\left(\mathrm{~S}_{275-295}\right)$ in the treatments with holothurians

$519(+\mathrm{H})$ and without holothurians $(-\mathrm{H})$ at the initial and final times. Red bars represent the

520 treatment with holothurians and grey bars represent the treatment without holothurians.

521 Asterisks show the statistically significant results at the final time of the experiments

522 (more details in Table 2). 


\section{Figure 1}

Exponential decay of absorption coefficients as wavelengths increase from the ultraviolet to the visible band

Example of a decay curve of the chromophoric dissolved organic matter in a sample taken on January $30^{\text {th }}$ of 2014 from the big-volume tank that contains holothurians. The wavelengths selected for the calculation of the optical parameters used in this study are marked on the decay curve.

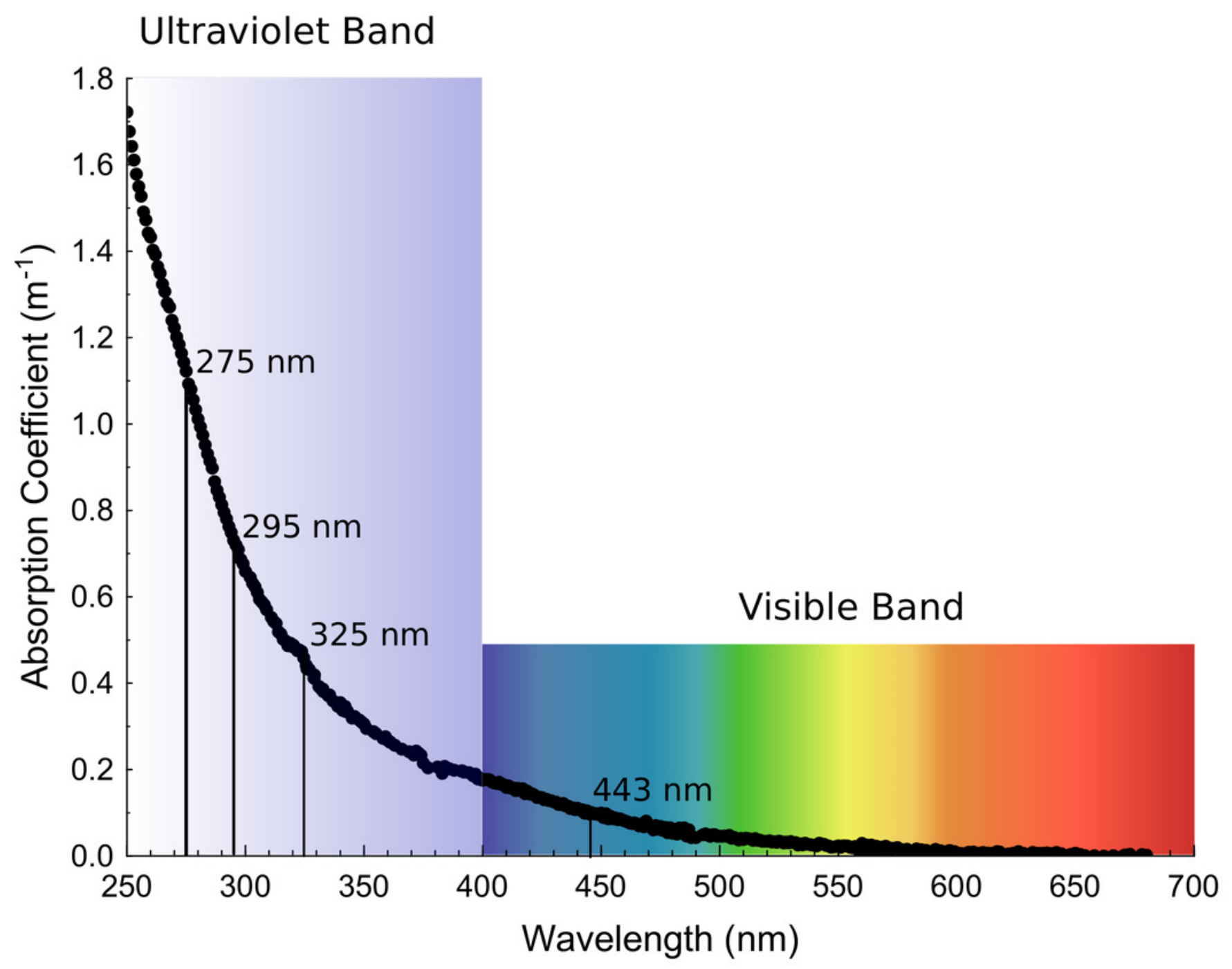


Figure 2

Time-series of the optical parameters of chromophoric dissolved organic matter in the big-volume tanks.

Values of (a) absorption coefficients at $325 \mathrm{~nm}\left(\mathrm{a}_{325}\right)$, (b) spectral slopes from 275 to $295 \mathrm{~nm}$ $\left(S_{275-295}\right)$, and (c) spectral slope ratios $\left(S_{R}\right)$ in the inlet water (white circles), in the effluent water of the +holothurian tank (red squares) and in the effluent water of the -holothurian tank (grey triangles). 
a

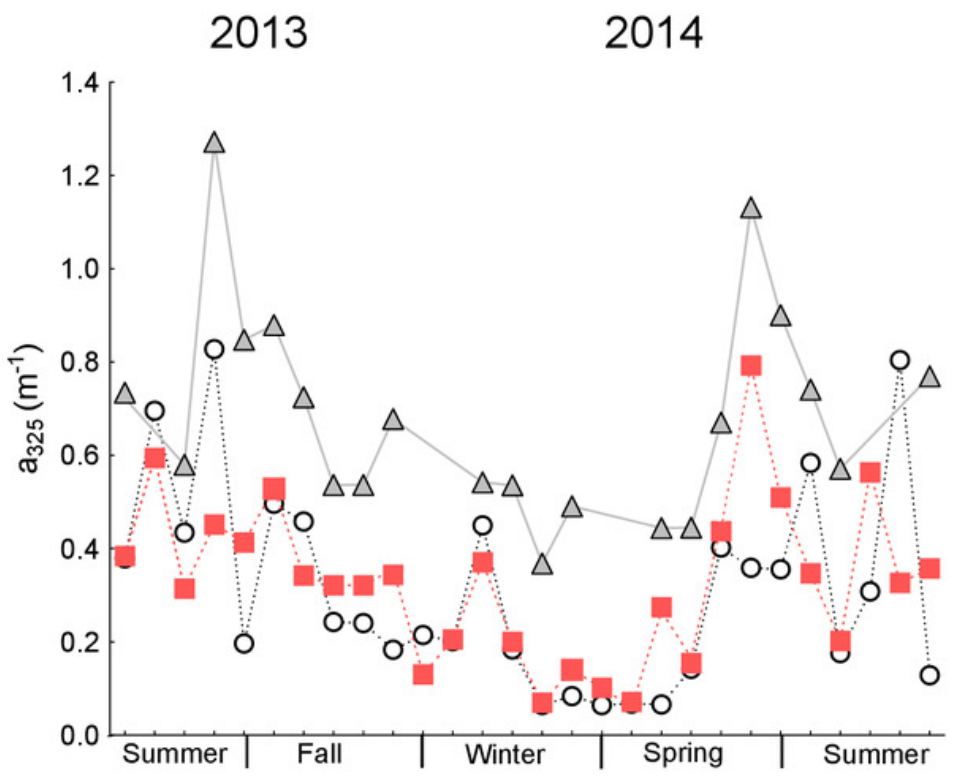

O Inlet waters

Effluent + holothurians

$\Delta$ Effluent - holothurians

b

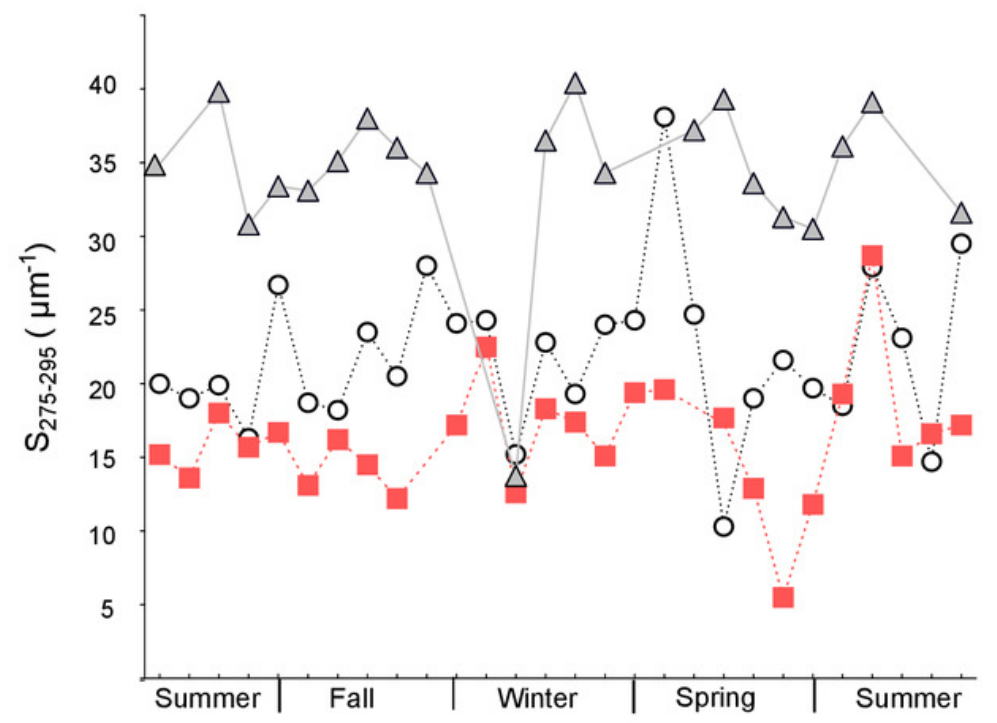

C

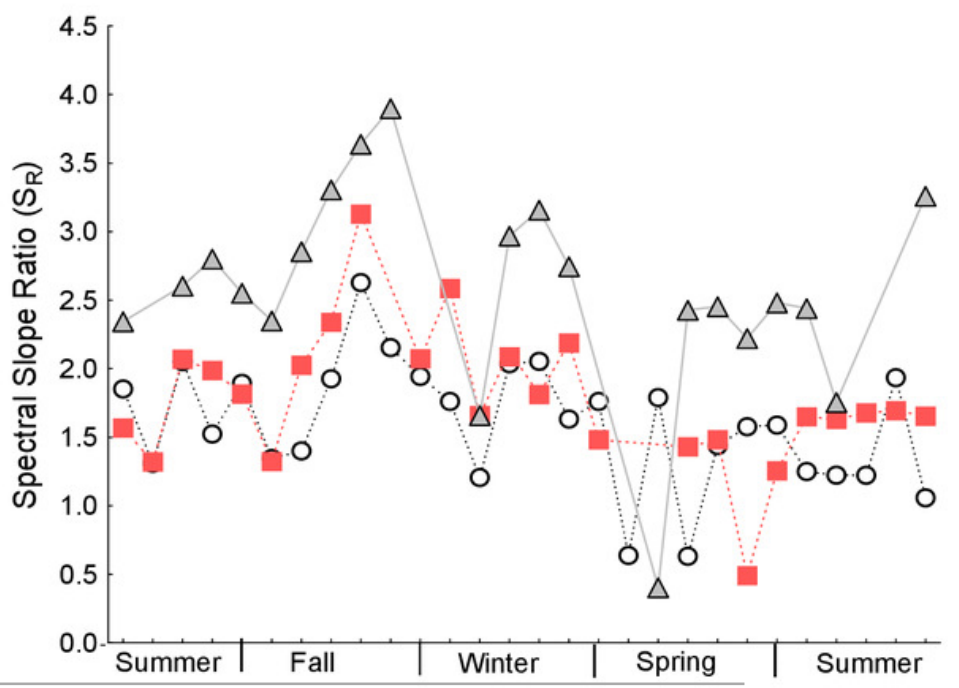




\section{Figure 3}

Median values (line), the $25-75 \%$ percentiles (box), and the non-outlier ranges (whisker) of the optical parameters of chromophoric dissolved organic matter pooling all timeseries data.

Values of (a) absorption coefficients at $325 \mathrm{~nm}\left(a_{325}\right)$, (b) spectral slopes from 275 to $295 \mathrm{~nm}$ $\left(\mathrm{S}_{275-295}\right)$ and (c) spectral slope ratios $\left(\mathrm{S}_{\mathrm{R}}\right)$ in the inlet water (white box), in the +holothurian effluent and tank (red boxes) and in the -holothurian effluent and tank (grey boxes). 

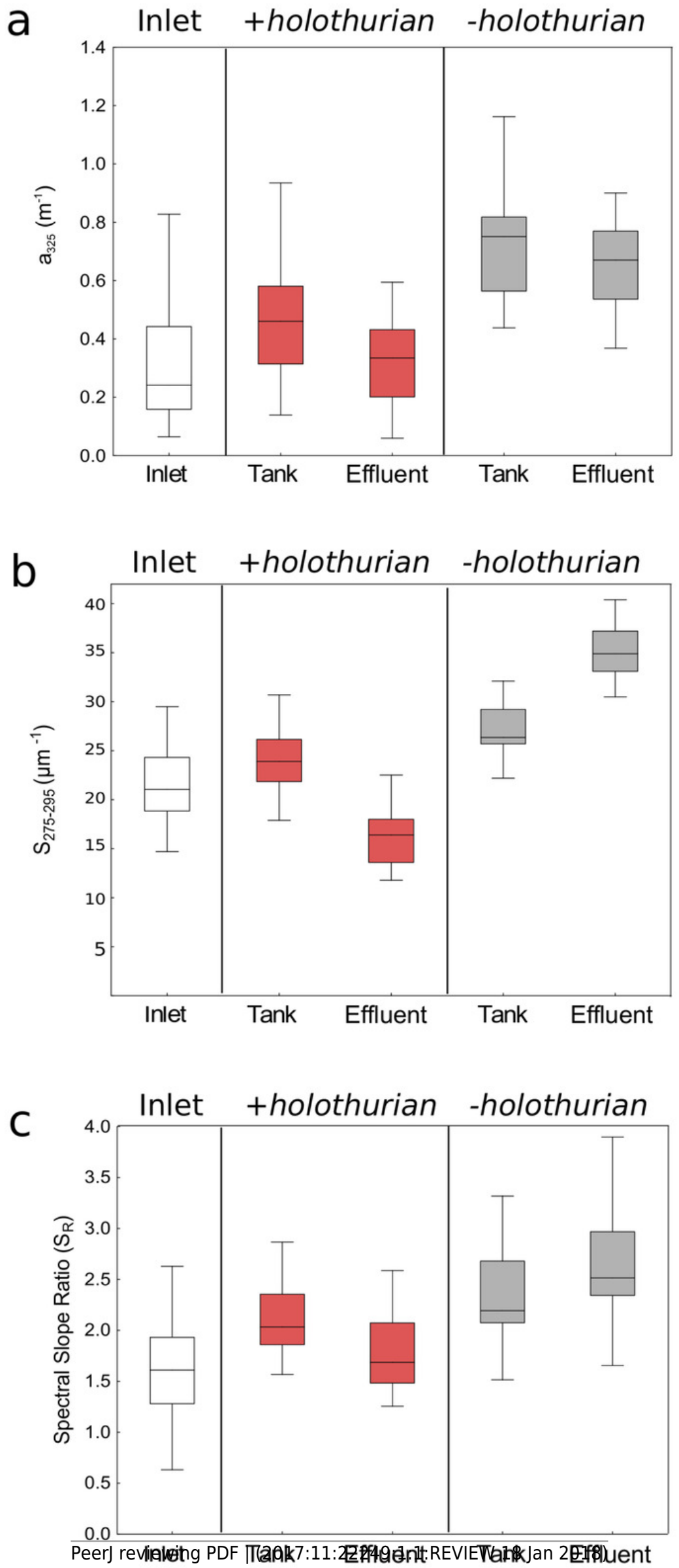


\section{Figure 4}

Scatterplots of absorption coefficients at $325 \mathrm{~nm}\left(\mathrm{a}_{325}\right)$ vs. bacterial abundance (a) and particulate organic matter (b) of the time-series data.

Red squares are the values for the +holothurian (effluent and tank) waters and grey triangles are the values for the -holothurian (effluent and tank) waters. Correlation lines are shown only when are statistically significant $(p<0.05)$. 

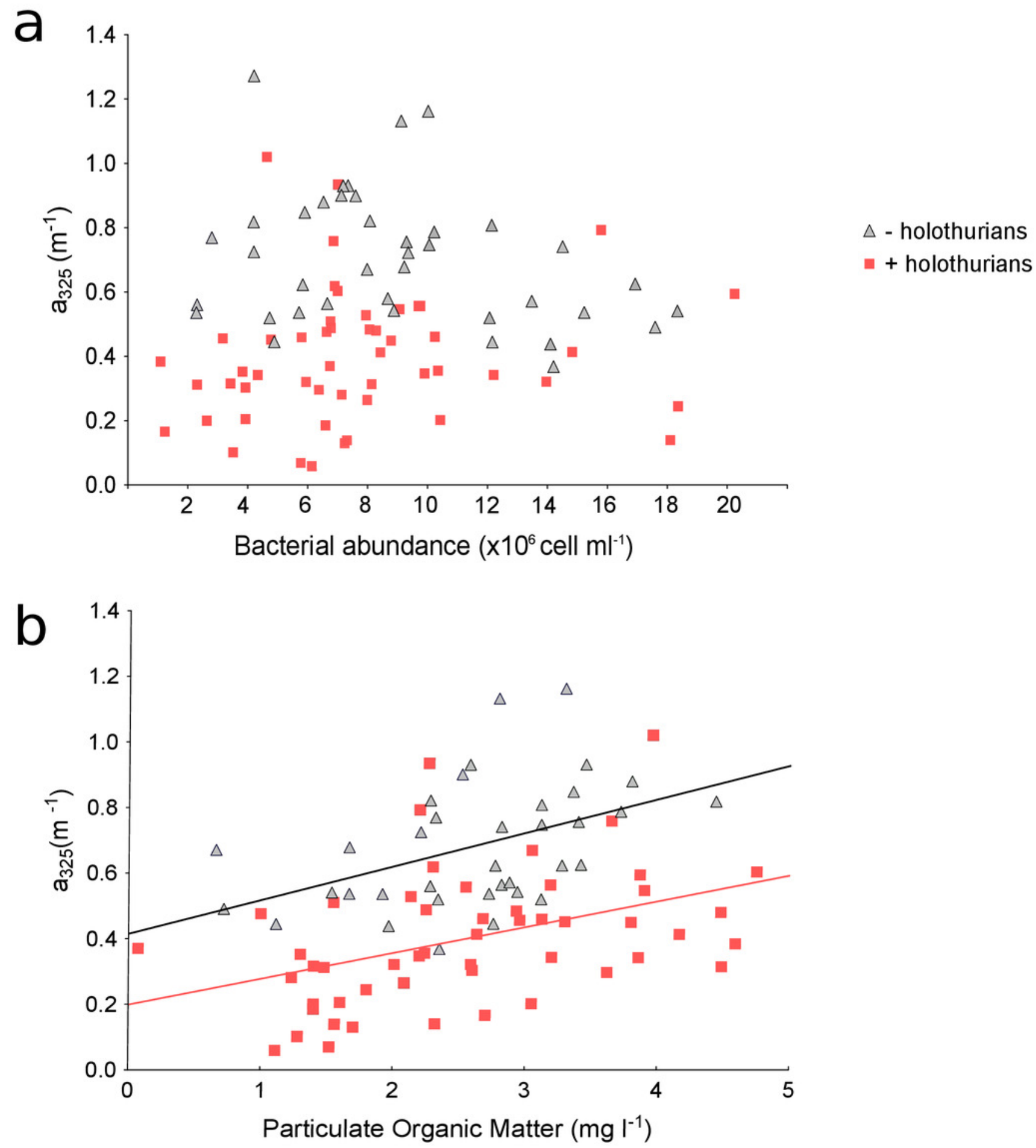


\section{Figure 5}

Changes in optical parameters of chromophoric dissolved organic matter in the three experiments.

Mean (bars) and the standard deviations (whiskers) of the replicates of (a) absorption coefficients at $325 \mathrm{~nm}\left(\mathrm{a}_{325}\right)$, (b) absorption coefficients at $443 \mathrm{~nm}\left(\mathrm{a}_{443}\right)$, and (c) spectral slopes from 275 to $295 \mathrm{~nm}\left(\mathrm{~S}_{275-295}\right)$ in the treatments with holothurians $(+\mathrm{H})$ and without holothurians $(-H)$ at the initial and final times. Red bars represent the treatment with holothurians and grey bars represent the treatment without holothurians. Asterisks show the statistically significant results at the final time of the experiments (more details in Table 2). 
a

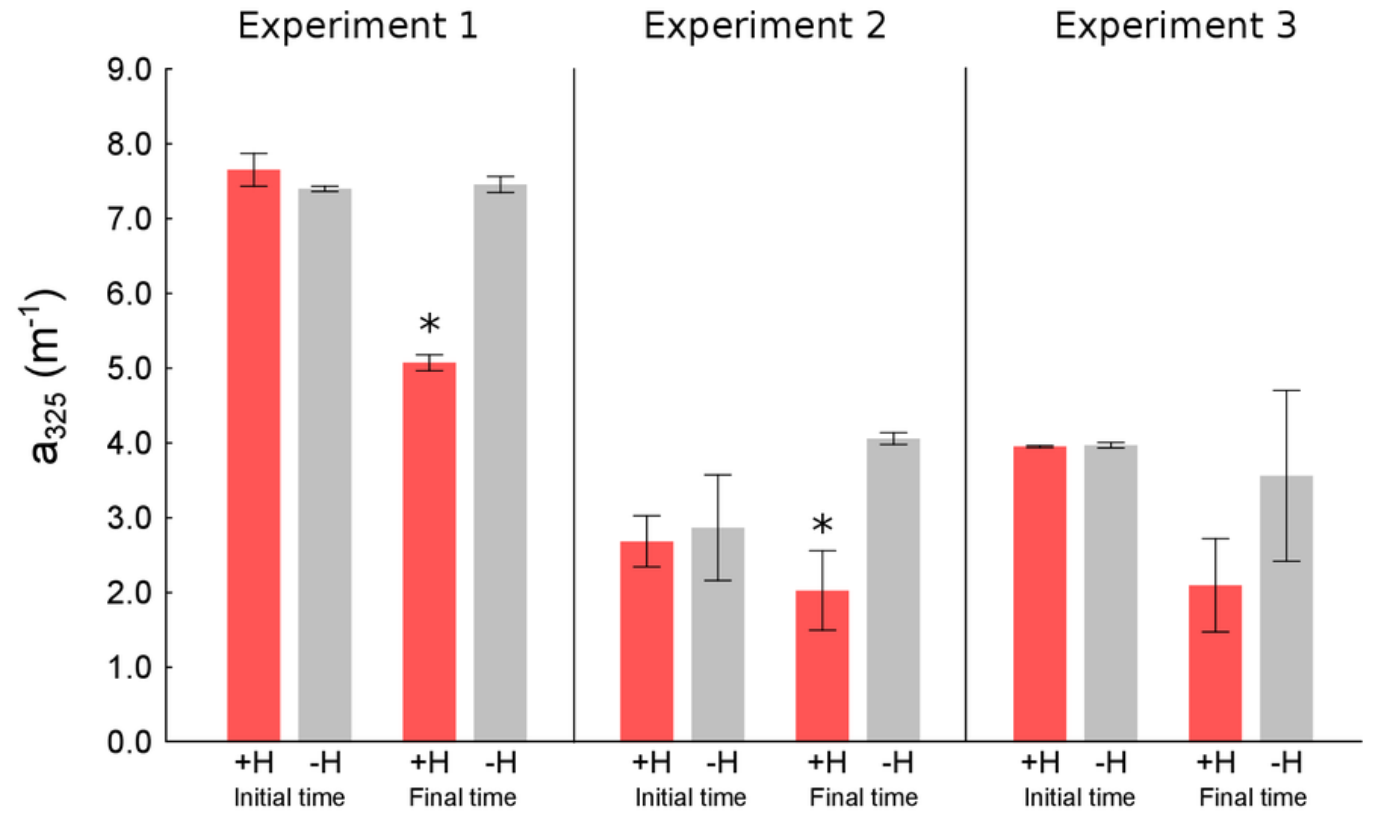

b

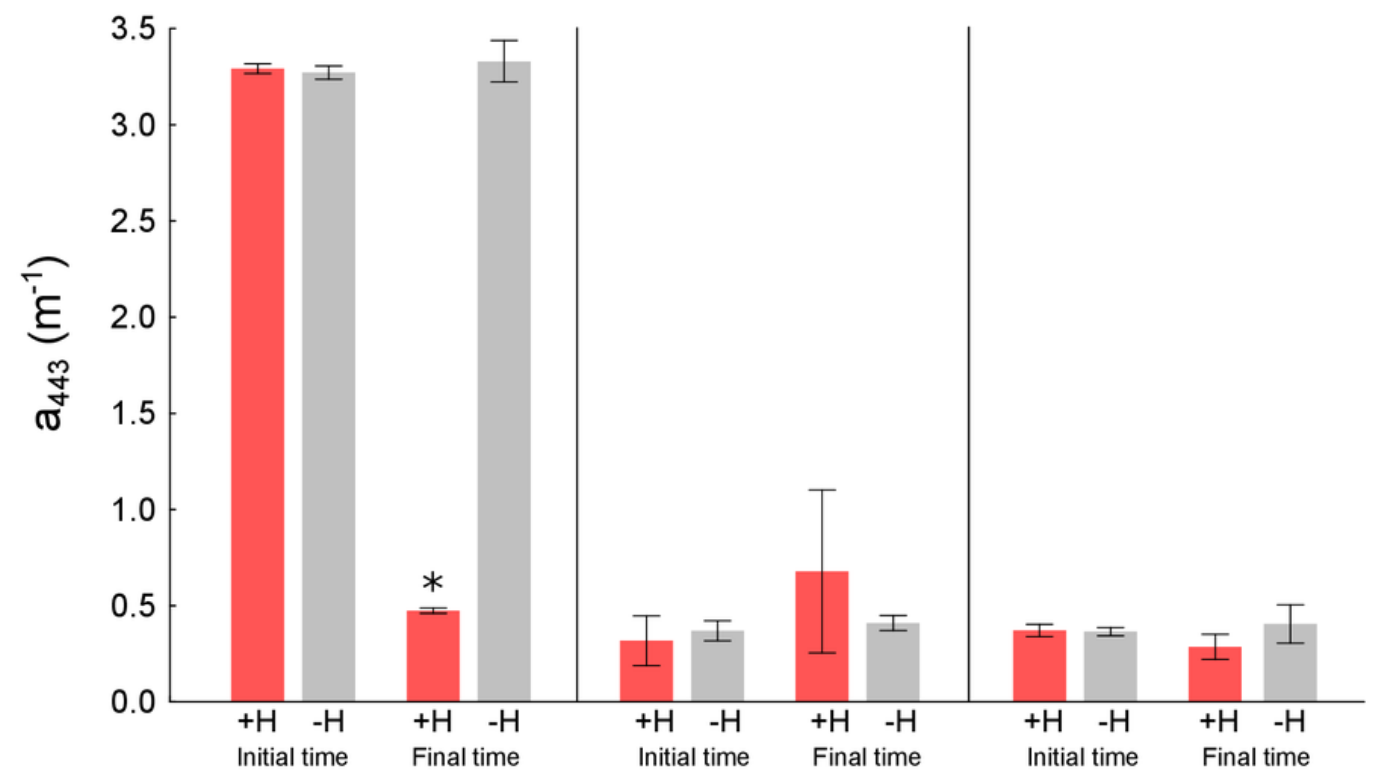

C

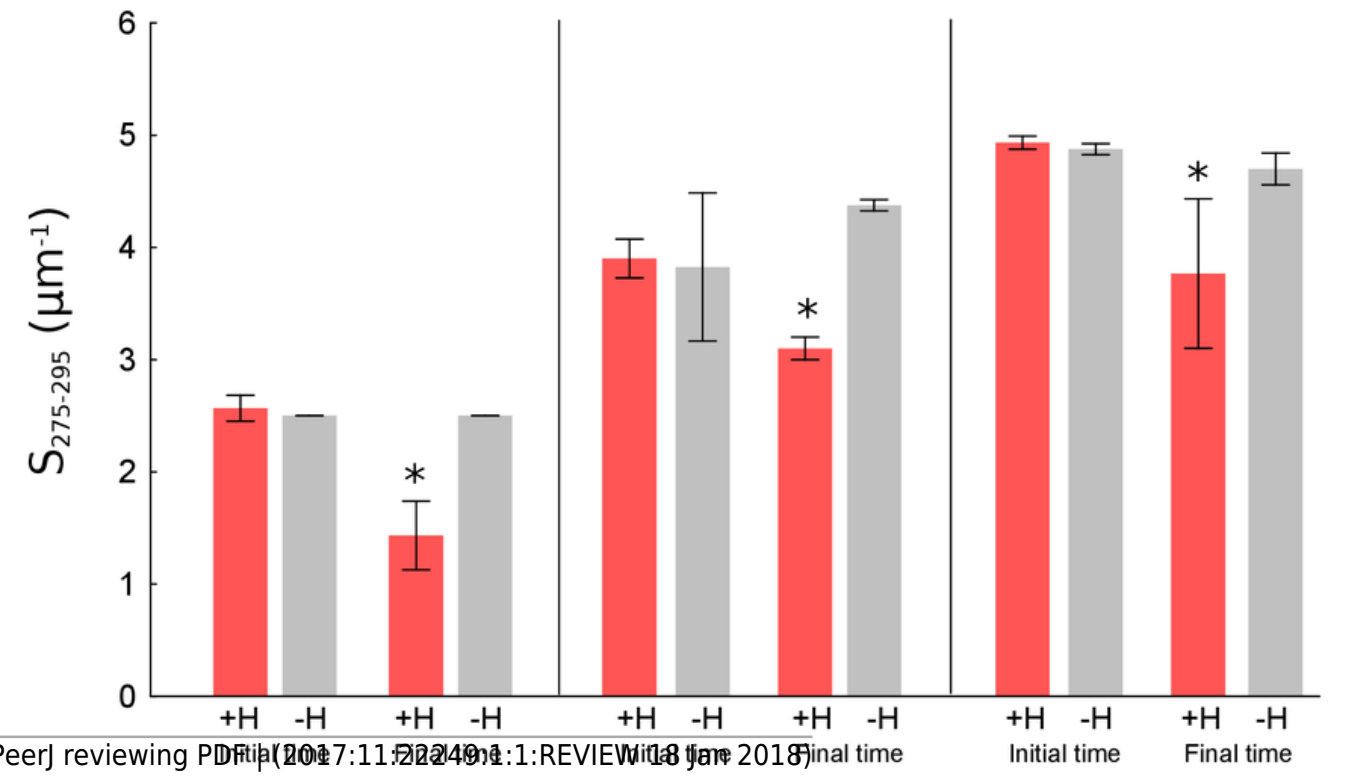




\section{Table $\mathbf{1}$ (on next page)}

Results of paired t-test and Wilcoxon matched pairs test between the inlet water and the effluent of the tank with holothurians and the effluent of the tank without holothurians.

Results of paired t-test (for normally distributed variables) and Wilcoxon matched pairs test (for not normally distributed variables) between the inlet water and the effluent of the tank with holothurians (+holothurians) and the effluent of the tank without holothurians (holothurian) for the CDOM optical properties considered in this study. Bold means that there is a significant difference. 
1 Table 1 Results of paired t-test (for normally distributed variables) and Wilcoxon matched pairs 2 test (for not normally distributed variables) between the inlet water and the effluent of the tank 3 with holothurians (+holothurians) and the effluent of the tank without holothurians (-holothurian) 4 for the CDOM optical properties considered in this study.

5 Bold means that there is a significant difference.

6

\begin{tabular}{|l|r|r|r|}
\hline \multicolumn{2}{|l|}{ Statistical Analysis } & $t$ or $z$ & $p$-value \\
\hline Inlet water vs. +holothurian effluent & \\
\hline Absorption coefficients $\left(\mathrm{a}_{325}\right)$ & Paired t-test & 19.67 & $\mathbf{0 . 0 0 0 0}$ \\
\hline Spectral slope $\left(\mathrm{S}_{275-295}\right)$ & Paired t-test & 4.86 & $\mathbf{0 . 0 0 0 0}$ \\
\hline Spectral slope ratio $\left(\mathrm{S}_{\mathrm{R}}\right)$ & Wilcoxon & 2.35 & $\mathbf{0 . 0 1 8 8}$ \\
\hline Inlet water vs. - holothurian effluent & & \\
\hline Absorption coefficients $\left(\mathrm{a}_{325}\right)$ & Paired t-test & 24.91 & $\mathbf{0 . 0 0 0 0}$ \\
\hline Spectral slope $\left(\mathrm{S}_{275-295}\right)$ & Wilcoxon & 3.98 & $\mathbf{0 . 0 0 0 0}$ \\
\hline Spectral slope ratio $\left(\mathrm{S}_{\mathrm{R}}\right)$ & Paired t-test & 6.18 & $\mathbf{0 . 0 0 0 0}$ \\
\hline +holothurian vs. - holothurian effluents & & \\
\hline Absorption coefficients $\left(\mathrm{a}_{325}\right)$ & Paired t-test & 11.45 & $\mathbf{0 . 0 0 0 0}$ \\
\hline Spectral slope $\left(\mathrm{S}_{275-295}\right)$ & Wilcoxon & 3.82 & $\mathbf{0 . 0 0 0 1}$ \\
\hline Spectral slope ratio $\left(\mathrm{S}_{\mathrm{R}}\right)$ & Wilcoxon test & 3.78 & $\mathbf{0 . 0 0 0 1}$ \\
\hline
\end{tabular}

7 


\section{Table 2 (on next page)}

Results of the analysis of variance (ANOVA) in the three experiments

Results of the analysis of variance (ANOVA) in the three experiments performed to compare the absorption coefficients at $325 \mathrm{~nm}\left(\mathrm{a}_{325}\right)$, the absorption coefficients at $443 \mathrm{~nm}\left(\mathrm{a}_{443}\right)$, and the spectral slopes from $275 \mathrm{~nm}$ to $295 \mathrm{~nm}\left(\mathrm{~S}_{275-295}\right)$ in the treatments with holothurians $(+\mathrm{H})$ vs. the treatments without holothurians $(-\mathrm{H})$ at initial and final times. 
Table 2 Results of the analysis of variance (ANOVA) in the three experiments performed to compare the absorption coefficients at $325 \mathrm{~nm}\left(\mathrm{a}_{325}\right)$, the absorption coefficients at $443 \mathrm{~nm}\left(\mathrm{a}_{443}\right)$, and the spectral slopes from $275 \mathrm{~nm}$ to $295 \mathrm{~nm}\left(\mathrm{~S}_{275-295}\right)$ in the treatments with holothurians $(+\mathrm{H})$ vs. the treatments without holothurians $(-\mathrm{H})$ at initial and final times.

\begin{tabular}{|c|c|c|c|c|c|c|}
\hline \multicolumn{7}{|c|}{ INITIAL TIME } \\
\hline & \multicolumn{2}{|c|}{ Experiment \# 1} & \multicolumn{2}{|c|}{ Experiment \# 2} & \multicolumn{2}{|c|}{ Experiment \# 3} \\
\hline & $F$ & p-value & $F$ & p-value & $F$ & p-value \\
\hline$a_{325}$ & 5.56 & 0.065 & 0.16 & 0.702 & 0.24 & 0.644 \\
\hline$a_{443}$ & 0.74 & 0.428 & 0.55 & 0.493 & 0.08 & 0.783 \\
\hline$S_{275-295}$ & 1.43 & 0.286 & 0.04 & 0.858 & 2.08 & 0.211 \\
\hline \multicolumn{7}{|c|}{ FINAL TIME } \\
\hline & \multicolumn{2}{|c|}{ Experiment \# 1} & \multicolumn{2}{|c|}{ Experiment \# 2} & \multicolumn{2}{|c|}{ Experiment \# 3} \\
\hline & $F$ & $p$-value & $F$ & $p$-value & $F$ & $p$-value \\
\hline$a_{325}$ & 849.74 & $<0.001$ & 60.99 & $<0.001$ & 3.92 & 0.105 \\
\hline$a_{443}$ & $\mathbf{1 9 8 0 . 1 5}$ & $<0.001$ & 1.70 & 0.249 & 3.14 & 0.137 \\
\hline$S_{275-295}$ & 571.43 & $<0.001$ & 506.69 & $<0.001$ & 7.89 & 0.038 \\
\hline
\end{tabular}

